\title{
Efficacy of Two Antibiotic-Extender Combinations on Mycoplasma bovis in Bovine Semen Production
}

\author{
Tarja Pohjanvirta ${ }^{1, *(\mathbb{D})}$, Nella Vähänikkilä ${ }^{1}$, Henri Simonen ${ }^{2}$, Sinikka Pelkonen ${ }^{1}$ and \\ Tiina Autio 1 (D) \\ 1 Finnish Food Authority, Laboratory and Research Division, Veterinary Bacteriology and Pathology Unit, \\ Neulaniementie 4, 70210 Kuopio, Finland; nella.vahanikkila@foodauthority.fi (N.V.); \\ sinikka.pelkonen@foodauthority.fi (S.P.); tiina.autio@foodauthority.fi (T.A.) \\ 2 VikingGenetics, Korpikyläntie 77, 15870 Hollola, Finland; hesim@vikinggenetics.com \\ * Correspondence: tarja.pohjanvirta@foodauthority.fi; Tel.: +358-447-201-493
}

Received: 21 August 2020; Accepted: 29 September 2020; Published: 30 September 2020 updates

\begin{abstract}
Mycoplasma bovis is an important bovine pathogen. Artificial insemination (AI) using contaminated semen can introduce the agent into a naïve herd. Antibiotics, most often gentamycin, tylosin, lincomycin, spectinomycin (GTLS) combination are added to semen extender to prevent transmission of pathogenic bacteria and mycoplasmas. In a commercial AI straw production system with industrial scale procedures, we analyzed the mycoplasmacidal efficacy of GTLS and ofloxacin on $M$. bovis ATCC and wild type strain isolated from commercial AI straws. The strains were spiked at two concentrations $\left(10^{6}\right.$ and $\left.10^{3} \mathrm{CFU} / \mathrm{mL}\right)$ into semen. Viable $M$. bovis in frozen semen straws was detected by enrichment culture and real-time PCR. We also compared different protocols to extract M. bovis DNA from spiked semen. None of the antibiotic protocols had any effect on the viability of either of the M. bovis strains at high spiking concentration. At low concentration, the wild type was inhibited by all other protocols, except low GTLS, whereas the ATCC strain was inhibited only by high GTLS. The InstaGene ${ }^{\mathrm{TM}}$ matrix was the most effective method to extract $M$. bovis DNA from semen. When there is a low M. bovis contamination level in semen, GTLS used at high concentrations, in accordance with Certified Semen Services requirements, is more efficient than GTLS used at concentrations stated in the OIE Terrestrial Code.
\end{abstract}

Keywords: Mycoplasma bovis; bovine semen; antibiotics; prevention; DNA extraction

\section{Introduction}

Mycoplasma bovis is a major bovine pathogen causing substantial economic losses and has a debilitating effect on animal welfare. M. bovis causes a variety of diseases including mastitis, pneumonia, arthritis, otitis media, and genital infections [1]. Efforts to develop efficacious vaccines have not been successful [2]. Once established in a cattle farm, M. bovis can be difficult to eradicate [3]. Consequently, it is of paramount importance to prevent the introduction of the agent into naïve herds.

One M. bovis transmission route into a herd is artificial insemination (AI) [4]. Recently, we reported on how contaminated semen used in AI, introduced $M$. bovis infection into closed naïve dairy herds [5]. In a previous study, heifers inseminated with semen containing $M$. bovis became repeat breeders, and only half of them finally conceived [6]. M. bovis could be isolated from cervico-vaginal mucus of some of the heifers, 8-32 weeks after insemination. Kissi et al. [7] showed that insemination with frozen Mycoplasma sp. containing semen often resulted in prolonged diestrus, suggesting that mycoplasma could initiate a pathological process in the uterus. However, very little is known about the concentration of $M$. bovis in naturally infected bull semen and the infectious dose needed to initiate an infection in the female genital system. 
There are several viral and bacterial pathogens that can be transmitted via semen [8]. Semen used for AI should be free of infectious agents. Several types of antibiotics have been added to seminal extenders before freezing to control bacterial contamination, including mycoplasmas. The World Organization for Animal Health OIE lists, in the OIE Terrestrial Code [9], the following three different antibiotic combinations to be used in international trade of bovine semen: gentamicin $(250 \mu \mathrm{g})$, tylosin $(50 \mu \mathrm{g})$, lincomycin-spectinomycin $(150 / 300 \mu \mathrm{g})$ (GTLS) in each $\mathrm{mL}$ of frozen semen; penicillin (500 IU), streptomycin $(500 \mu \mathrm{g})$, lincomycin-spectinomycin (150/300 $\mu \mathrm{g})$ (PSLS); or amikacin (75 $\mu \mathrm{g})$, divekacin $(25 \mu \mathrm{g})$. The European Union directive 88/407/1993 includes the use of the above mentioned PSLS, or an alternative combination of antibiotics with an equivalent effect against campylobacters, leptospires, and mycoplasmas. Shin et al. [10], in 1988, developed a method where GTLS concentration was doubled as compared with the concentration stated in OIE Code, and GTLS was first added into raw semen before extending with GTLS containing extender. Nowadays, GTLS is widely used in bovine semen production, and Certified Semen Services (CSS) in USA has a special protocol in place for GTLS use [11]. However, Visser et al. conducted two studies, in 1995 and 1999 [12,13], in which they questioned the ability of even the high GTLS concentration to control M. bovis in AI. Since the studies of Shin et al. [10] and Visser et al. [12,13], animal protein sources in commercial extenders have often been replaced with plant protein sources such as soybean lecithin to avoid disease transmission through the use of animal source protein [14]. Most commercially available soy-lecithin-based extenders contain GTLS as standard antibiotics. However, recent $M$. bovis isolates have shown a marked increase in MIC90 values for tylosin, lincomycin, and spectinomycin, but resistance against fluoroquinolones is still quite rare [15-17]. Recently a fluoroquinolone antibiotic, ofloxacin, was shown to be non-toxic to spermatozoa and effective in protecting semen from bacteria, although the authors did not analyze its effect on mycoplasmas [18].

Introductions of M. bovis into countries free of the organism have recently been reported (Finland 2012 [19], New Zealand 2017, (https://www.mpi.govt.nz/protection-and-response/mycoplasma-bovis/). Although these introductions have not been directly linked to semen, $M$. bovis risk, due to global semen trade, continues to be a concern, especially in New Zealand where eradication of M. bovis has been attempted. In this study, we evaluated the efficacy of the low OIE Code and the high CSS guideline GTLS concentrations and two ofloxacin concentrations on the viability of two different M. bovis strains in spiked frozen semen. We used an ATCC strain, as well as a wild type strain recently isolated from commercial AI semen straws [5]. Unlike in previous GTLS efficacy studies [10,12,13], we used a commercial animal protein free extender. We wanted to study if it was possible to achieve mycoplasmacidal effect, in other words, no detection of M. bovis in AI semen straws after semen was enriched in mycoplasma broth, and an aliquot of the broth culture was directly analyzed using M. bovis real-time polymerase chain reaction (PCR).

Mycoplasmas are fastidious organisms needing special culture media and expertise in isolation. Instead of mycoplasma culture, PCR could be an option in AI centers to ensure M. bovis-free semen lots. There are only a few studies about PCR detection of $M$. bovis in bovine semen. Therefore, we also evaluated sensitivity of different DNA extraction methods to detect $M$. bovis in semen.

Experiments to produce M. bovis contaminated AI straws were conducted, in a commercial AI straw producing laboratory, using industrial scale procedures. This was possible because semen production ceased in this center after these experiments.

\section{Results}

Raw pooled semen showed no growth in mycoplasma culture. M. bovis or Friis broth did not have any detrimental effect on quality parameters of semen (Table 1).

After storage of the AI straws for five weeks in liquid nitrogen, at high spiking concentrations $\left(10^{6} \mathrm{CFU} / \mathrm{mL}\right)$, viable $M$. bovis bacteria were detected in processed semen regardless of the processing protocol. When low M. bovis concentrations were inoculated, differences among processing protocols were seen (Table 2). At a low spiking concentration, the ATCC strain was more resistant than the wild 
type strain to different antibiotics. The only protocol inhibiting the growth of the ATCC strain was the high GTLS 500/100/300/600 $\mu \mathrm{g} / \mathrm{mL}$ (final concentration in extended semen) supplement added in the semen lab to the extender. All protocols, except EU GTLS 250/50/150/300 $\mu \mathrm{g} / \mathrm{mL}$ (final concentration in extended semen) and extender without antibiotics, inhibited the growth of the wild type at a low spiking concentration.

Table 1. Semen quality parameters of raw and spiked semen.

\begin{tabular}{ccccc}
\hline Semen & Strain (CFU/mL) & Motility $\%$ & Viability $\%$ & Sperm Concentration $(\mathbf{1 0} \mathbf{6} / \mathbf{m L})$ \\
\hline Raw semen & & 75.0 & 82.5 & 1850 \\
Processed semen & ATCC $10^{3}$ & $55 \pm 2.9$ & $53 \pm 3.0$ & $65 \pm 2.9$ \\
& ATCC $10^{6}$ & $56 \pm 6.1$ & $53 \pm 2.5$ & $67 \pm 2.3$ \\
& wild type $10^{3}$ & $52 \pm 5.5$ & $52 \pm 2.1$ & $67 \pm 2.1$ \\
& wild type $10^{6}$ & $57 \pm 5.5$ & $52 \pm 4.6$ & $67 \pm 2.3$ \\
& unspiked & $53 \pm 5.1$ & $54 \pm 2.3$ & $61 \pm 1.3$ \\
\hline
\end{tabular}

Table 2. Detection of M. bovis wild type and ATCC 27368 by culture (+/-) from three parallel pooled samples (e.g., + + +) from different antibiotic/extender protocols after five-week storage of the straws in liquid nitrogen. Concentration used in spiking and culture dilution are shown in the table.

\begin{tabular}{|c|c|c|c|c|c|c|}
\hline \multirow[b]{2}{*}{$\begin{array}{l}\text { Culture dilution } \\
\text { Wild type strain }\end{array}$} & \multicolumn{3}{|c|}{$10^{3} \mathrm{CFU} / \mathrm{mL}$} & \multicolumn{3}{|c|}{$10^{6} \mathrm{CFU} / \mathrm{mL}$} \\
\hline & -2 & -3 & -4 & -2 & -3 & -4 \\
\hline GTLS 500/100/300/600 a & --- & -- & -- & -- & +++ & +++ \\
\hline CSS GTLS ${ }^{b}$ & - & -- & -- & - & -- & +++ \\
\hline EU GTLS $^{c}$ & - & --+ & - & - & +++ & +++ \\
\hline $\mathrm{OF} 400 \mu \mathrm{g}^{\mathrm{d}}$ & - &.- & - & - & +++ & +++ \\
\hline OF $100 \mu \mathrm{g}$ & -- & --- & -- & --- & +++ & +++ \\
\hline $\begin{array}{l}\text { no antibiotic } \\
\text { ATCC strain }\end{array}$ & +++ & +-+ & +-- & +++ & +++ & +++ \\
\hline GTLS 500/100/300/600 & -- & --- & --- & +-- & --- & +++ \\
\hline CSS GTLS & - & -- & -+- & +++ & -+- & +++ \\
\hline EU GTLS & - & +++ & +-- & -- & +++ & +++ \\
\hline OF $400 \mu \mathrm{g}$ & -- & --+ & +-+ & +-+ & +++ & +++ \\
\hline $\mathrm{OF} 100 \mu \mathrm{g}$ & - - - & +++ & -++ & +-- & +++ & +++ \\
\hline no antibiotic & +++ & +++ & ++- & +++ & +++ & +++ \\
\hline
\end{tabular}

a gentamycin $(500 \mu \mathrm{g} / \mathrm{mL})$, tylosin $(100 \mu \mathrm{g} / \mathrm{mL})$, lincomycin $(300 \mu \mathrm{g} / \mathrm{mL})$, spectinomycin $(600 \mu \mathrm{g} / \mathrm{mL}) ;{ }^{\mathrm{b}}$ Certified Semen Services gentamycin $(500 \mu \mathrm{g} / \mathrm{mL})$, tylosin $(100 \mu \mathrm{g} / \mathrm{mL})$, lincomycin $(300 \mu \mathrm{g} / \mathrm{mL})$, spectinomycin $(600 \mu \mathrm{g} / \mathrm{mL})$ protocol; ${ }^{c}$ gentamycin $(250 \mu \mathrm{g} / \mathrm{mL})$, tylosin $(50 \mu \mathrm{g} / \mathrm{mL})$, lincomycin $(150 \mu \mathrm{g} / \mathrm{mL})$, spectinomycin $(300 \mu \mathrm{g} / \mathrm{mL})$; d ofloxacin.

Antimicrobials present in extended semen affect the mycoplasma culture, and thus several dilutions were made. In samples with high concentration of antimicrobials, viable $M$. bovis could be detected only in the highest culture dilution (Table 2).

We compared three different DNA extraction methods for spiked semen samples. At a high spiking concentration $\left(10^{6} \mathrm{CFU} / \mathrm{mL}\right)$, all pools were positive in PCR regardless of the DNA extraction method. Ct values varied between 24.7 and 28.5, and no significant differences in $\mathrm{Ct}$ values among extraction methods were seen (data not shown).

At a low spiking concentration, the method using InstaGene ${ }^{\mathrm{TM}}$ (method three) was the most effective. Using this method, we detected M. bovis in $94 \%(17 / 18)$ of pools spiked with $10^{3} \mathrm{CFU} / \mathrm{mL}$ of ATCC strain, and in $72 \%(13 / 18)$ spiked with $10^{3} \mathrm{CFU} / \mathrm{mL}$ of wild type strain. With method one, $67 \%(12 / 18)$ and with method two, 56\% (10/18) of pools spiked with ATCC strain were positive in PCR, respectively. For the wild type strain, respective figures were for method one $61 \%(11 / 18)$ and $33 \%(6 / 18)$ for method two (Table 3). The Ct values varied between 34.3 and 36.7, and no significant differences in $\mathrm{Ct}$ values among extraction methods were seen (data not shown). 
Table 3. Comparison of three different DNA extraction methods for detection of M. bovis in semen using oppD real-time PCR. Results (+/-) from three parallel pools (e.g., +++ ) from each antibiotic protocol are shown.

\begin{tabular}{|c|c|c|c|c|c|c|c|c|c|c|c|c|}
\hline & \multicolumn{6}{|c|}{$10^{3} \mathrm{CFU} / \mathrm{mL}$} & \multicolumn{6}{|c|}{$10^{6} \mathrm{CFU} / \mathrm{mL}$} \\
\hline & \multicolumn{3}{|c|}{ ATCC } & \multicolumn{3}{|c|}{ Wild Type } & \multicolumn{3}{|c|}{ АТСС } & \multicolumn{3}{|c|}{ Wild Type } \\
\hline & Method $1^{a}$ & Method $2^{b}$ & Method $3^{c}$ & Method 1 & Method 2 & Method 3 & Method 1 & Method 2 & Method 3 & Method 1 & Method 2 & Method 3 \\
\hline $\begin{array}{c}\text { GTLS } \\
500 / 100 / 300 / 600\end{array}$ & -++ & ++- & +++ & +-- & +-+ & +-- & +++ & +++ & +++ & +++ & +++ & +++ \\
\hline CSS GTLS & +-- & -++ & +++ & -++ & - - - & +++ & +++ & +++ & +++ & +++ & +++ & +++ \\
\hline EU GTLS & +++ & ++- & +++ & +++ & +-+ & -++ & +++ & +++ & +++ & +++ & +++ & +++ \\
\hline OF $400 \mu \mathrm{g}$ & +++ & +-+ & +++ & +-+ & - - - & ++- & +++ & +++ & +++ & +++ & +++ & +++ \\
\hline OF $100 \mu \mathrm{g}$ & -+- & --+ & +-+ & -+- & -- & +++ & +++ & +++ & +++ & +++ & +++ & +++ \\
\hline Control & -++ & --+ & +++ & -++ & ++- & +-+ & +++ & +++ & +++ & +++ & +++ & +++ \\
\hline
\end{tabular}

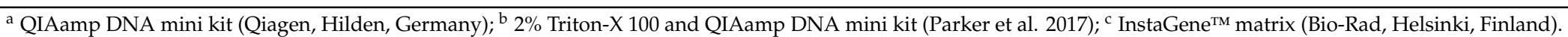


Minimum inhibitory concentration values of the strains used in spiking are shown in Table 4 .

Table 4. MIC values ( $\mu \mathrm{g} / \mathrm{mL})$ of ATCC 27368 and wild type strains (dilution range of antibiotic tested).

\begin{tabular}{cccc}
\hline Antibiotic & Dilution Range Tested $\mu \mathrm{g} / \mathbf{m L}$ & ATCC 27368 & Wild Type \\
\hline Tylosin & $0.5-32$ & $\leq 0.5$ & 16 \\
Lincomycin & $0.25-32$ & 2 & 1 \\
Spectinomycin & $2-128$ & 4 & $\leq 2$ \\
Enrofloxacin & $0.03-2$ & 0.25 & 0.25 \\
Danofloxacin & $0.03-2$ & 0.25 & 0.25 \\
\hline
\end{tabular}

\section{Discussion}

Our study showed that it is challenging to rely on the use of antibiotics in bovine semen production to control M. bovis. None of the studied antibiotics had any effect on viability of $M$. bovis at $10^{6} \mathrm{CFU} / \mathrm{mL}$ in extended semen, and the lower spiking concentration of $10^{3} \mathrm{CFU} / \mathrm{mL}$ gave discrepant results. The high GTLS concentration reduced the number of viable $M$. bovis below the level of detection in all but one pool when $10^{3} \mathrm{CFU} / \mathrm{mL}$ was spiked. In contrast, using the low concentration EU GTLS protocol, four out of six pools were positive in culture, suggesting that the GTLS concentration stated in the OIE Code is not high enough to eliminate even a low concentration of M. bovis in semen.

Our results on efficacy of GTLS are in line with previous studies by Shin et al. [10] and Visser et al. [12,13], although there are marked differences in experimental setup among the studies. In our study, an AI straw production system was performed in a commercial facility using industrial scale procedures, the wild type study strain had been recently isolated from AI straws, different extenders and treatments were used, and survival of $M$. bovis was measured using a different method. In the earlier studies $[10,12,13]$, animal protein containing extenders were used, as well as a plate counting method was used to detect viable $M$. bovis. Shin et al. [10] found that a high GTLS concentration in $20 \%$ egg yolk citrate extender showed $85 \%$ reduction of viable $M$. bovis. GTLS in other extenders was less mycoplasmacidal, thus, extender composition seemed to affect the efficacy of GTLS on M. bovis. However, the opinion of Shin et al. [10] was that the reduction of M. bovis concentration was so notable that it made the semen safe to use, and Shin's GTLS protocol was implemented for use in the Unites States AI industry. Later, Visser et al. [12,13] studied the effect of high GTLS in egg yolk tris extender. They noticed a one to two decimal reduction in M. bovis numbers in some batches, and in some batches the number of viable $M$. bovis was even higher in the GTLS-treated semen as compared with non-treated semen. We did not attempt to analyze the number of colony-forming units after liquid nitrogen storage. Instead, we aimed to find any viable $M$. bovis cells by enrichment culture and using real-time PCR to detect $M$. bovis in broth cultures. Previously, we showed that the limit of detection of this method was $1.4 \times 10^{2} \mathrm{CFU} / \mathrm{mL}$ of $M$. bovis PG45 in fresh, non-frozen extended bull semen [20]. Animal protein-free extender used in this study did not seem to enhance the efficacy of antibiotics as compared with earlier studies. The inclusion of further field strains isolated from AI semen in this study would have been appropriate, but these were not readily available.

Macrolide and linco/spectinomycin resistance, in recent $M$. bovis isolates from Europe, has increased as compared with isolates before $2000[15,17]$. This may have an impact on the effect of GTLS in $M$. bovis in semen as the highest dilutions tested in recent European studies [16,21] were from 64 to $256 \mu \mathrm{g} / \mathrm{mL}$, and several strains had MIC values higher than the highest tested concentration. Antimicrobial susceptibility studies [15-17,21,22] showed that contemporary M. bovis strains are susceptible to fluoroquinolones, except for a few strains that had $\mathrm{MIC}_{90}$ over $32 \mu \mathrm{g} / \mathrm{mL}$. Gloria et al. [18] reported that ofloxacin, a fluoroquinolone antibiotic, had non-significant effects on sperm quality and controlled bacteria efficiently in semen doses, although they did not study the effect on mycoplasmas. This tempted us to examine the effect of two different ofloxacin concentrations on M. bovis in semen. To our knowledge, this is the first publication on efficacy of a fluoroquinolone on M. bovis in commercial semen production. Although the ATCC strain used for spiking had an MIC value of $0.25 \mu \mathrm{g} / \mathrm{mL}$ for enrofloxacin and 
danofloxacin, the $100 \mu \mathrm{g} / \mathrm{mL}$ ofloxacin concentration in extender had no effect on the viability of the ATCC strain, and two out of three tested pools of the high ofloxacin concentration were also culture positive. Antimicrobial resistance, in the strains we used in this study did not explain the results, as MIC values for tylosin, lincomycin, and spectinomycin, as well as for fluoroquinolones, were well below the concentrations of antibiotics in semen extenders. The biological conditions for antibiotics to act with M. bovis in MIC testing are remarkably different as compared with conditions in semen production.

Most antibiotics require ongoing cell activity or cell division to be able to destroy bacteria. Low temperature can keep bacteria in a stationary phase of growth, thus, making the antibiotics almost ineffective. This is considered in the EU directive 88/407/1993 which states that extended semen with antibiotics must be kept a minimum of $45 \mathrm{~min}$ at $5{ }^{\circ} \mathrm{C}$, and in the CSS protocol that requires, first, adding antibiotics in raw semen, and then keeping extended semen at $5{ }^{\circ} \mathrm{C}$ for a minimum of two hours before freezing. In our study, extended semen with different antibiotics was kept for 3-3.5 h at temperatures (decreasing from $34^{\circ} \mathrm{C}$ to $17^{\circ} \mathrm{C}$ ) that, in theory, allowed replication of mycoplasmas. Thus, the negative effect of low temperature on antimicrobial effect cannot explain our results.

A possible way to control the dissemination of M. bovis via AI could be testing of raw semen or multiple straws of extended semen using PCR. However, PCR inhibitors present in semen can pose problems for detecting $M$. bovis. Semen contains very high amounts of DNA and protein, potassium ions, citric acids, and fructose. Therefore, it is essential to have a highly sensitive method for DNA isolation from bull semen. We compared three different DNA extraction methods and found that InstaGene ${ }^{\mathrm{TM}}$ proved to be the most efficient and robust method to detect $M$. bovis DNA in extended bull semen. To our knowledge, Parker et al. [23] and McDonald [24] are the only studies on the sensitivity of real-time PCR detection of M. bovis in semen. Parker et al. [23] used the Triton-X extraction method which, in our study, had lower sensitivity than the InstaGene ${ }^{\mathrm{TM}}$ method. Together with the uvrC gene-based real-time PCR, their limit of detection was $1.3 \times 10^{5} \mathrm{CFU} / \mathrm{mL}$, which was higher than for our method. McDonald [24] used a commercial DNA isolation kit on spiked semen and multiplex real-time PCR targeting fus $A$ and $o p p D / F$ genes. These assays detected $3.1 \times 10^{3} \mathrm{M}$. bovis genomes per $\mathrm{mL}$ semen, which was a similar level of detection to our InstaGene ${ }^{\mathrm{TM}}$ method. Little is known about shedding of $M$. bovis into semen during different stages of infection. It is generally known that shedding of mycoplasmas into semen can be intermittent. Ball et al. [25] showed that at least three semen lots from a bull needed to be analyzed to find out if the bull was shedding mycoplasmas into semen. This has also been shown for the secretion of M. bovis to semen. A clinically healthy bull in the AI center was shown to shed M. bovis in semen for a very short period and intermittently [5]. Our culture and PCR results also highlight the problem that $M$. bovis seems to be unequally distributed in extended semen, a phenomenon we also saw when examining the straws from the naturally infected bull semen. Therefore, it is important to analyze several straws, even from the same lot, when trying to detect $M$. bovis in semen. We also found that, within the same lot, some straws were positive only in PCR, but unculturable [5]. This can lead to unnecessary disposing of semen lots that contain only dead bacteria.

AI using M. bovis-contaminated semen can introduce the agent into naïve dairy herds. We showed that even using modern commercial extender and industrial procedures, neither GTLS nor ofloxacin reached $100 \%$ bactericidal effect on M. bovis. Our results suggest that regarding M. bovis in semen, it is safer to use the high 500/100/300/600 $\mu \mathrm{g} / \mathrm{mL}$ GTLS concentration. To be able to fully understand the risk of $M$. bovis contaminated semen in dairy herds and to know if it is even necessary to have zero tolerance for $M$. bovis in commercial semen, we need to know what is the M. bovis load that would initiate a pathological process in the female genital system.

Another option, although very laborious, is to test processed semen for the presence of M. bovis, considering the special features of $M$. bovis infection in bulls and occurrence in semen. However, the increasing antimicrobial resistance in contemporary M. bovis strains, the difficulties achieving $100 \%$ mycoplasmacidal effect using antibiotics in semen, and the pressure to reduce the amount of antibiotics used in semen industry calls for future attempts to allow only M. bovis negative bulls into semen production. 


\section{Materials and Methods}

\subsection{Semen Collection and Quality Assessment}

All studies were done in a commercial AI straw producing AI center's laboratory using industrial scale procedures. This was possible because the semen production ceased in this center after these experiments. Semen from three bulls was collected into sterile collection tubes at the AI center of VikingGenetics, Hollola, Finland. The motility of each semen batch was evaluated microscopically at $200 \times$ magnification using prewarmed glass slides and coverslips. Viability and concentration of each batch was analyzed using flow cytometry (CyFlow, Partec, Germany). Pooled raw semen (0.3 mL) was cultured in Friis broth [26] to detect possible Mycoplasma contamination. The final sperm cell concentration was 12-13 million per straw. On the basis of the weight and concentration, the volume of extender was calculated.

\subsection{Mycoplasma Bovis Strains}

Two M. bovis strains were used in spiking, i.e., a wild type isolate from commercial AI straws (strain 198, [5]) and a reference strain ATCC 27368. Strains were cultured in Friis broth in closed tubes at $37^{\circ} \mathrm{C}$, for $70 \pm 2 \mathrm{~h}$. High $\left(10^{8} \mathrm{CFU} / \mathrm{mL}\right)$ and low $\left(10^{5} \mathrm{CFU} / \mathrm{mL}\right)$ concentration stock solutions were made from the cultures in Friis broth. To verify the M. bovis concentration of the stocks, ten-fold dilutions were made and plated on Friis plates. Plates were incubated at $37^{\circ} \mathrm{C}$, in $5 \% \mathrm{CO}_{2}$, for 7 days, and colony-forming units were counted.

\subsection{Protocols Used for Processing Semen}

Semen from the three bulls was pooled and divided into 30 aliquots which were kept at $32{ }^{\circ} \mathrm{C}$. Commercial animal protein-free extender base containing $7 \%$ glycerol was used in all protocols. Six antibiotic protocols were compared as follows: (1) GTLS (500/100/300/600 $\mu \mathrm{g} / \mathrm{mL}$, respectively) fresh antibiotic supplemented extender; (2) raw semen was treated with GTLS fresh antibiotics for $3 \mathrm{~min}$ and further extended with GTLS (500/100/300/600 $\mu \mathrm{g} / \mathrm{mL}$, respectively) fresh antibiotic supplemented extender (according to Certified Semen Services (CSS) requirements), later called CSS GTLS; (3) GTLS (250/50/150/300 $\mu \mathrm{g} / \mathrm{mL}$, respectively), antibiotic supplemented extender (ready to use liquid concentrate containing antibiotics), according to the OIE Code, Article 4.7.7, later called EU GTLS; (4) ofloxacin $100 \mu \mathrm{g} / \mathrm{mL}$ (Sigma Aldrich 33703) antibiotic supplemented extender; or (5) ofloxacin $400 \mu \mathrm{g} / \mathrm{mL}$ antibiotic supplemented extender; and (6) extender without antibiotics, control. The final concentration of the $M$. bovis strains in extended semen was either $10^{6} \mathrm{CFU} / \mathrm{mL}$ or $10^{3} \mathrm{CFU} / \mathrm{mL}$. Friis broth was used as a negative control in each different antibiotic/extender aliquot. The protocols are described in Table 5. All extenders, antibiotics, and Friis broth were kept at $32{ }^{\circ} \mathrm{C}$ before being added into the semen. All protocols, except number two (CSS GTLS), included diluting the semen in 1:1extender (with or without antibiotics) and Friis broth containing either $10^{8}$ or $10^{5}$ CFU M. bovis ATCC or wild type. In protocol two (CSS GTLS), GTLS was first diluted 1:4 in sterile water and $38 \mu \mathrm{L}$ added into neat semen $(380 \mu \mathrm{L}), M$. bovis culture $(118 \mu \mathrm{L})$ yielding the same antibiotic concentration as if $20 \mu \mathrm{L}$ GTLS mixture (500/100/300/600) would have been added directly to raw semen. After 3 min of incubation at $32{ }^{\circ} \mathrm{C}$, the semen was further diluted 1:1 with extender containing GTLS. Then, all aliquots were incubated for one hour at $34^{\circ} \mathrm{C}$, after which they were diluted further with extender with or without antibiotics to give the final concentration of 56 million sperm cells $/ \mathrm{mL}$. Then, the temperature of the aliquots was allowed to stabilize to room temperature (approximately one hour) after which automatic semen straw filling and sealing machine (MPP Quattro, Minitube, Germany) was used. Semen was packed into $0.25 \mathrm{~mL}$ straws. After packing, the straws were cooled to $17^{\circ} \mathrm{C}$ for one hour and further cooled quickly to $4{ }^{\circ} \mathrm{C}$. The straws were kept at $4{ }^{\circ} \mathrm{C}$ overnight and they were deep-frozen with industrial semen straw freezer (Digitcool 5300, IMV, France) the next morning. Cryopreserved straws were stored in liquid nitrogen storage tank $\left(-196^{\circ} \mathrm{C}\right)$ until they were analyzed. 
Table 5. Antibiotic/extender protocols used for processing semen.

\begin{tabular}{|c|c|c|c|c|c|}
\hline GTLS (500/100/300/600) & CSS GTLS (500/100/300/600) & EU GTLS (250/50/150/300) & OF400 & OF100 & Control \\
\hline $0.38 \mathrm{~mL}$ semen & $0.38 \mathrm{~mL}$ semen & $0.38 \mathrm{~mL}$ semen & $0.38 \mathrm{~mL}$ semen & $0.38 \mathrm{~mL}$ semen & $0.38 \mathrm{~mL}$ semen \\
\hline+ & + & + & + & + & + \\
\hline $0.38 \mathrm{~mL}$ GTLS extender & $0.118 \mathrm{~mL}$ M.bovis & $0.38 \mathrm{~mL}$ GTLS extender & $0.38 \mathrm{~mL}$ OF extender & $0.38 \mathrm{~mL}$ OF extender & $\begin{array}{l}0.38 \mathrm{~mL} \text { extender } \\
\text { no antibiotic }\end{array}$ \\
\hline+ & + & + & + & + & + \\
\hline $0.118 \mathrm{~mL}$ M. bovis & $\begin{array}{c}38 \mu \mathrm{L} \text { GTLS } 1: 4 \\
3 \mathrm{~min}\end{array}$ & $0.118 \mathrm{~mL}$ M. bovis & $0.118 \mathrm{~mL}$ M. bovis & $0.118 \mathrm{~mL}$ M. bovis & $0.118 \mathrm{~mL}$ M. bovis \\
\hline+ & $\begin{array}{c}+ \\
0.38 \mathrm{~mL} \text { GTLS extender } \\
+\end{array}$ & + & + & + & + \\
\hline $1 \mathrm{~h} 34^{\circ} \mathrm{C}$ & $1 \mathrm{~h} 34^{\circ} \mathrm{C}$ & $1 \mathrm{~h} 34^{\circ} \mathrm{C}$ & $1 \mathrm{~h} 34{ }^{\circ} \mathrm{C}$ & $1 \mathrm{~h} 34^{\circ} \mathrm{C}$ & $1 \mathrm{~h} 34{ }^{\circ} \mathrm{C}$ \\
\hline+ & + & + & + & + & + \\
\hline 10.875 mL GTLS extender & 10.875 mL GTLS extender & 10.875 mL GTLS extender & $10.875 \mathrm{~mL}$ OF extender & $10.875 \mathrm{~mL}$ OF extender & $\begin{array}{c}10.875 \text { mL extender } \\
\text { no antibiotic }\end{array}$ \\
\hline \multicolumn{6}{|c|}{$\begin{array}{l}\text { Room temperature } 50-90 \text { min and packing in straws }(0.25 \mathrm{~mL} \text { per straw }) \\
\qquad \begin{array}{c}1 \mathrm{~h}+17^{\circ} \mathrm{C} \\
21 \mathrm{~h}+4^{\circ} \mathrm{C} \\
\text { Storage in liquid nitrogen }\end{array}\end{array}$} \\
\hline
\end{tabular}




\subsection{Semen Quality Parameters after Thawing}

After 18 days storage in liquid nitrogen, two straws from each trial lot were thawed. The motility was assessed under phase contrast microscope. Flow cytometric analysis was used to evaluate viability and concentration of sperm cells.

\subsection{Viability Testing of M. Bovis from Semen Straws Stored in Liquid Nitrogen}

After storage of five weeks in liquid nitrogen, 18 straws from each of the 30 trial lots were randomly retrieved from the nitrogen tank. They were divided into three pools, each consisting of six straws. Straws were thawed and the content of the six straws was pooled. From each pool, $0.6 \mathrm{~mL}$ of semen was used in three different DNA extraction procedures described in Section 4.6., and $0.3 \mathrm{~mL}$ of semen was placed into $2.7 \mathrm{~mL}$ of Friis broth. Ten-fold dilutions, up to $10^{-5}$, were made into Friis broth in tightly closed tubes. Broth cultures were incubated at $37^{\circ} \mathrm{C}$ for 14 days. The growth and color change of the medium were monitored every other day, and broths suspected of mycoplasma growth were plated on Friis agar and tested for M. bovis using real-time PCR targeting M. bovis oppD gene [27]. From each trial lot, all broth culture dilutions from $10^{-2}$ to $10^{-4}$ were tested for $M$. bovis, as described above, at the latest, immediately after the 14-day incubation period.

\subsection{DNA Extraction from Semen Straws after Storage in Liquid Nitrogen}

Three different protocols to extract DNA from spiked semen were compared. In each method, $200 \mu \mathrm{L}$ of semen was used as a starting material. Method one was automated DNA extraction using a QIAcube (Qiagen, Hilden, Germany) robot and blood and body fluids protocol with QIAamp DNA mini kit. The elution volume was $150 \mu \mathrm{L}$. In method two [25], $200 \mu \mathrm{L}$ of semen was combined with $200 \mu \mathrm{L}$ of $2 \%$ Triton-X 100 (Sigma Aldrich) in $10 \mathrm{mM}$ Tris and $1 \mathrm{mM}$ EDTA (pH 8) buffer. The sample was thoroughly vortexed and pelleted at $13,000 \times g$ for $5 \mathrm{~min}$. DNA was extracted from the pellet using the QIAcube robot and bacterial pellet protocol with QIAamp DNA mini kit. The elution volume was $150 \mu \mathrm{L}$. Method three was modified from the OIE Terrestrial Manual method to isolate DNA from bovine semen for herpesvirus PCR (chapter 3.4.11, adopted May 2017). In method three, $200 \mu \mathrm{L}$ of semen was centrifuged at $13,000 \times \mathrm{g}$ for $10 \mathrm{~min}$ and supernatant was discarded. The pellet was mixed with $200 \mu \mathrm{L}$ of InstaGene ${ }^{\mathrm{TM}}$ matrix (Bio-Rad, Helsinki, Finland), $5.8 \mu \mathrm{L}$ proteinase $\mathrm{K}(20 \mathrm{mg} / \mathrm{mL})$, and $7.5 \mu \mathrm{L}$ DL-dithiothreitol $(1 \mathrm{M})$. Samples were incubated at $56^{\circ} \mathrm{C}$, for $30 \mathrm{~min}$, and then vortexed at high speed for $10 \mathrm{~s}$. The tubes were boiled in water bath $\left(100^{\circ} \mathrm{C}\right)$ for $8 \mathrm{~min}$, and then vortexed at high speed for $10 \mathrm{~s}$. Then, the tubes were centrifuged at 10,000 $\mathrm{g}$ for $3 \mathrm{~min}$. The supernatant was transferred into a new microtube and stored at $-20^{\circ} \mathrm{C}$.

\subsection{M. bovis Real-Time PCR}

Broth cultures and DNA extracted from semen straw pools were examined by real-time PCR (CFX96 Touch Real-Time PCR Detection System, Bio-Rad, CA, USA) targeting oppD-gene of M. bovis, as described previously by Sachse et al [27]. Friis broth cultures were prepared for real-time PCR as follows: First, $200 \mu \mathrm{L}$ of broth culture was incubated for $15 \mathrm{~min}$ at $95^{\circ} \mathrm{C}$ and centrifuged at $10,000 \times \mathrm{g}$ for $5 \mathrm{~min}$. Two $\mu \mathrm{L}$ of culture supernatant or DNA was used as PCR template. Commercially available plasmid pUC19 was used as internal amplification control, according to Fricker et al. [28].

\subsection{Determining Minimal Inhibitory Concentration (MIC) of Wild Type Strain and ATCC 27368}

MICs were determined using custom made Sensititre plates (Thermo Fisher Scientific, UK). Antibiotics tested were tylosin (concentration range $0.5-32 \mu \mathrm{g} / \mathrm{mL}$ ), lincomycin $(0.25-32 \mu \mathrm{g} / \mathrm{mL}$ ), spectinomycin $(2-128 \mu \mathrm{g} / \mathrm{mL})$, enrofloxacin $(0.03-2 \mu \mathrm{g} / \mathrm{mL})$, and danofloxacin $(0.03-2 \mu \mathrm{g} / \mathrm{mL})$. Testing was done according to $[15,16]$. Briefly, a suspension containing $5 \%$ growth indicator alamarBlue (Thermo Fisher Scientific, United Kingdom) in Friis broth without antibiotics and M. bovis $5 \times 10^{5} \mathrm{CFU} / \mathrm{mL}$ was made, and $200 \mu \mathrm{L}$ of the suspension was pipetted into each well of the Sensititre plate. Plates were 
sealed and incubated at $37^{\circ} \mathrm{C}$ for $48 \pm 1 \mathrm{~h}$ and read visually; blue indicating no growth and red indicating growth of the isolate. MIC was the lowest concentration of antibiotic completely suppressing growth (blue color).

Author Contributions: Conceptualization, T.P., N.V., T.A., and S.P.; methodology, T.P., N.V., and T.A.; formal analysis, T.P., N.V., and T.A.; investigation, N.V. and H.S.; resources, H.S.; writing-original draft preparation, T.P.; writing - review and editing, T.P., T.A., H.S., and S.P.; supervision, T.A.; project administration and funding acquisition, S.P. All authors have read and agreed to the published version of the manuscript.

Funding: This research was funded by the Ministry of Agriculture and Forestry of Finland, grant number 1490/03.01.02//2016.

Acknowledgments: We are grateful to Riikka Luukkanen and Petra Väisänen for excellent technical assistance. We thank DVM Kasia Kupisiewicz for critical reding of the manuscript.

Conflicts of Interest: Henri Simonen is employed by VikingGenetics, however, experiments, interpretation of results, and manuscript preparation has been done independently. The funders had no role in the design of the study; in the collection, analyses, or interpretation of data; in the writing of the manuscript, or in the decision to publish the results.

\section{References}

1. Maunsell, F.P.; Woolums, A.R.; Francoz, D.; Rosenbusch, R.F.; Step, D.L.; Wilson, D.J.; Janzen, E.D. Mycoplasma bovis infections in cattle. J. Vet. Intern. Med. 2011, 25, 772-783. [CrossRef] [PubMed]

2. Perez-Casal, J.; Prysliak, T.; Maina, T.; Suleman, M.; Jimbo, S. Status of the development of a vaccine against Mycoplasma bovis. Vaccine 2017, 35, 2902-2907. [CrossRef] [PubMed]

3. Nicholas, R.A. Bovine mycoplasmosis: Silent and deadly. Vet. Rec. 2011, 168, 459-462. [CrossRef]

4. Pfützner, H.; Sachse, K. Mycoplasma bovis as an agent of mastitis, pneumonia, arthritis and genital disorders in cattle. Rev. Sci. Tech. 1996, 15, 1477-1494. [CrossRef]

5. Haapala, V.; Pohjanvirta, T.; Vähänikkilä, N.; Halkilahti, J.; Simonen, H.; Pelkonen, S.; Soveri, T.; Simojoki, H.; Autio, T. Semen as a source of Mycoplasma bovis mastitis in dairy herds. Vet. Microbiol. 2018, 216, 60-66. [CrossRef] [PubMed]

6. Hirth, R.S.; Nielsen, S.W.; Plastridge, W.N. Bovine salpingo-oophoritis produced with semen containing a Mycoplasma. Pathol. Vet. 1966, 3, 616-632. [CrossRef]

7. Kissi, B.; Juhász, S.; Stipkovits, L. Effect of mycoplasma contamination of bull semen on fertilization. Acta Vet. Hung. 1985, 33, 107-117.

8. Wentink, G.H.; Frankena, K.; Bosch, J.C.; Vandehoek, J.E.D.; van den Berg, T. Prevention of disease transmission by semen in cattle. Livest. Prod. Sci. 2000, 62, 207-220. [CrossRef]

9. OIE Terrestrial Animal Health Code, Chapter 4.7. Available online: https://www.oie.int/index.php?id=169\& $\mathrm{L}=0 \&$ htmfile=chapitre_coll_semen.htm (accessed on 5 August 2020).

10. Shin, S.J.; Lein, D.H.; Patten, V.H.; Ruhnke, H.L. A new antibiotic combination for frozen bovine semen 1. Control of mycoplasmas, ureaplasmas, Campylobacter fetus subsp. venerealis and Haemophilus somnus. Theriogenology 1988, 29, 577-591. [CrossRef]

11. CSS-National Association of Animal Breeders. Available online: https://www.naab-css.org/uploads/ userfiles/files/CSSMinReq-Jan2014201607-ENG.pdf (accessed on 5 August 2020).

12. Visser, I.J.R.; ter Laak, E.A.; Jansen, H.B.; Gerard, O. The effect of antibiotic mixtures on Haemophilus somnus, Campylobacter fetus spp. venerealis, Mycoplasma bovis, and Ureaplasma diversum in frozen bovine semen. Reprod. Domest. Anim. 1995, 30, 55-59. [CrossRef]

13. Visser, I.J.; ter Laak, E.A.; Jansen, H.B. Failure of antibiotics gentamycin, tylosin, lincomycin and spectinomycin to eliminate Mycoplasma bovis in artificially infected frozen bovine semen. Theriogenology 1999, 51, 689-697. [CrossRef]

14. Rehman, F.; Zhao, C.; Shah, M.A.; Qureshi, M.S.; Wang, X. Semen extenders and artificial insemination in ruminants. Veterinaria 2013, 1, 1-8.

15. Ayling, R.D.; Rosales, R.S.; Barden, G.; Gosney, F.L. Changes in antimicrobial susceptibility of Mycoplasma bovis isolates from Great Britain. Vet. Rec. 2014, 175, 486. [CrossRef] [PubMed]

16. Heuvelink, A.; Reugebrink, C.; Mars, J. Antimicrobial susceptibility of Mycoplasma bovis isolates from veal calves and dairy cattle in the Netherlands. Vet. Microbiol. 2016, 189, 1-7. [CrossRef] 
17. Klein, U.; de Jong, A.; Youala, M.; El Garch, F.; Stevenin, C.; Moyaert, H.; Rose, M.; Catania, S.; Gyuranecz, M.; Pridmore, A.; et al. New antimicrobial susceptibility data from monitoring of Mycoplasma bovis isolated in Europe. Vet. Microbiol. 2019, 238, 108432. [CrossRef]

18. Gloria, A.; Contri, A.; Wegher, L.; Vignola, G.; Dellamaria, D.; Carluccio, A. The effects of antibiotic additions to extenders on fresh and frozen-thawed bull semen. Anim. Reprod. Sci. 2014, 150, 15-23. [CrossRef] [PubMed]

19. Vähänikkilä, N.; Pohjanvirta, T.; Haapala, V.; Simojoki, H.; Soveri, T.; Browning, G.F.; Pelkonen, S.; Wawegama, N.K.; Autio, T. Characterisation of the course of Mycoplasma bovis infection in naturally infected dairy herds. Vet. Microbiol. 2019, 231, 107-115. [CrossRef]

20. Vähänikkilä, N.; Pohjanvirta, T.; Vaahtoranta, L.; Silvennoinen, M.; Skovgaard Jensen, S.K.; Pelkonen, S.; Autio, T. Detection of Mycoplasma bovis in bovine semen-An interlaboratory trial. In Proceedings of the 22nd Congress of the International Organization for Mycoplasmology, Portsmouth, NH, USA, 9-12 July 2018; Brown, D., Wells, N., Eds.; p. 143.

21. Sulyok, K.M.; Kreizinger, Z.; Fekete, L.; Hrivnák, V.; Magyar, T.; Jánosi, S.; Schweitzer, N.; Turcsányi, I.; Makrai, L.; Erdélyi, K.; et al. Antibiotic susceptibility profiles of Mycoplasma bovis strains isolated from cattle in Hungary, Central Europe. BMC Vet. Res. 2014, 10, 256. [CrossRef]

22. Gautier-Bouchardon, A.V.; Ferré, S.; Le Grand, D.; Paoli, A.; Gay, E.; Poumarat, F. Overall decrease in the susceptibility of Mycoplasma bovis to antimicrobials over the past 30 years in France. PLoS ONE 2014, 9, e87672. [CrossRef]

23. Parker, A.M.; House, J.K.; Hazelton, M.S.; Bosward, K.L.; Sheehy, P.A. Comparison of culture and a multiplex probe PCR for identifying Mycoplasma species in bovine milk, semen and swab samples. PLoS ONE 2017, 12, e0173422. [CrossRef]

24. McDonald, K.M. The Development of a Dual Target Mycoplasma Bovis TaqMan Real-Time PCR System for Rapid Analysis of Bovine Semen. Master's Thesis, The Ohio State University, Columbus, OH, USA, 2012.

25. Ball, H.J.; Logan, E.F.; Orr, W. Isolation of mycoplasmas from bovine semen in Northern Ireland. Vet. Rec. 1987, 121, 322-324. [CrossRef] [PubMed]

26. Bölske, G. Survey of mycoplasma infections in cell cultures and a comparison of detection methods. Zentralbl. Bakteriol. Mikrobiol. Hyg. Ser. A 1988, 269, 331-340. [CrossRef]

27. Sachse, K.; Salam, H.S.H.; Diller, R.; Schubert, E.; Hoffmann, B.; Hotzel, H. Use of a novel real-time PCR technique to monitor and quantitate Mycoplasma bovis infection in cattle herds with mastitis and respiratory disease. Vet. J. 2010, 186, 299-303. [CrossRef] [PubMed]

28. Fricker, M.; Messelhäußer, U.; Busch, U.; Schere, S.; Ehling-Schultz, M. Diagnostic real-time PCR assays fot the detection of emetic Bacillus cereus strains in food and recent food-borne outbreaks. Appl. Environ. Microbiol. 2007, 73, 1892-1898. [CrossRef] [PubMed]

(C) 2020 by the authors. Licensee MDPI, Basel, Switzerland. This article is an open access article distributed under the terms and conditions of the Creative Commons Attribution (CC BY) license (http://creativecommons.org/licenses/by/4.0/). 